\title{
Determination of the Visual Preferences of Different Habitat Types
}

\section{Engin Eroglu ${ }^{1}$, Sertaç Kaya ${ }^{1}$, Tuba Gul Dogan ${ }^{1}$, Alperen Meral2 ${ }^{*}$, Sena Demirci ${ }^{1}$, Nermin Başaran ${ }^{1}$ Omer Lutfu Corbaci ${ }^{3}$}

1 Department of Landscape Architecture, Faculty of Forestry, Duzce University, Duzce, 81620, Turkey; engineroglu@duzce.edu.tr (E.E), sertackaya@duzce.edu.tr (S.K), tubacakir1989@hotmail.com (T.G.D), senademirci53@gmail.com (S.D), nerminbasaran@duzce.edu.tr (N.B.)

2 Department of Landscape Architecture, Faculty of Agriculture, Bingol University, Bingol, 12000, Turkey; alperenmeral@bingol.edu.tr

3 Department of Landscape Architecture, Faculty Fine Arts Design and Architecture, Recep Tayyip Erdogan University, Rize, 53100, Turkey; omerlutfu.corbaci@erdogan.edu.tr

\section{* Correspondence: alperenmeral@bingol.edu.tr}

\begin{abstract}
The unique qualities of areas with natural landscape features help provide sustainability. Moreover, their different vegetation covers and ecosystems contribute to the preservation of their visual attraction. In recent years, the demand for natural areas has not only been seen at a recreational level, but has also become associated with the conservation and sustainability of those areas. Although the concept of sustainability is expressed from an ecological point of view, studies indicate that the visual aspect is also an important component. Thus, in this study, a visual quality assessment was carried out which considered both objective and subjective evaluations of different habitat types. Efteni lakewetland and Melen Ağzı dunes (Düzce), Anzer, Ayder, and Çat Düzü highlands (Rize), and Sultanmurat and Taşli highlands (Trabzon) were selected as the study areas. A visual quality analysis was conducted with a total of 43 participants (23 students, 16 local inhabitants and four lecturers) in order establish their preferences in areas with different landscape characteristics. For the determination of the visual qualifications of these areas, a total of 24 photographs showing typical images representing each habitat type (three photographs for each) were employed. Taking perceptual parameters into consideration, assessment of visual quality was made according to the points given to each photo by the participants. Consequently, differences in visual quality were found to be influenced by the demographic status of the participants, differences in habitat types, recreational trends and the conservation status of the habitats.
\end{abstract}

Keywords: Habitat types, visual differences, landscape characteristics.

\section{Introduction}

Green and natural areas are an important part of the ecosystem as well as being important for their positive effects on the human psyche (Khew et al., 2014). Today, considering the destruction and economic exploitation of these areas, their ecological importance is not always being taken into account. However, plants are an important source of that most basic of life requirements- oxygen, and thus, are very important indeed for the existence of future generations. In order to establish this perception, people must be made to understand through their own experience by spending time in natural surroundings that they need these areas. They must become aware that life is not possible without natural areas and therefore, these green areas must be maintained and their sustainability must be ensured for the future of human wellbeing. Today, the construction projects resulting from increasing human demands create pressure on urban green spaces, are not in harmony with existing historical buildings and disrupt the traditional texture of the city. This negative situation weakens the relationship between Man and the environment and contributes to the deterioration of the environmental 
perceptibility. For these reasons, environmental issues are often disregarded and rejected (Özkan et al., 2015).

With the decline of open green spaces, awareness of the importance of nature and the value of the management of natural resources is rapidly increasing (Erdönmez and Kaptanoğlu, 2008). In order to preserve the diversity of natural landscapes, the importance of visual landscape quality as well as natural resource value must be considered (Sarı and Karaşah, 2015). Visual landscape quality is a term which emerged as a result of landscape evaluations made from the perceptual and emotional perspectives of the viewers (Kıroğlu, 2007). Visual landscape has an important place in the human life experience (Lambe, 1986). The visual components of the landscape reveal not only aesthetic values, but also the cultural, economic and biological interrelationships of these values (Daniel and Vining, 1983; Amir and Gidalizon, 1990; Angileri and Toccolini, 1993). Today, visual quality assessment has become more important for data collection in planning studies. The purpose of visual quality assessment is to determine whether a landscape is aesthetically appropriate and to define some of the factors that affect the preferences for certain areas and physical landscape components (Kane, 1981).

In recent years, natural beauty has become one of the most important criteria for evaluating landscape. One reason for this is thought to be that people's visual perception is more developed than other types of perception (Kaplan and Kaplan, 1989). Therefore, visual quality can be seen as an important part of the human-environment interaction (Parsons and Daniel, 2000). As well as the mental, physical and socio-economic differences among people, there are also differences in their evaluation of visual preferences for landscape (Sevenant and Antrop, 2010).

Visual preferences are generally evaluated by research methods such as surveys. Researchers ask participants to select or score their favorite photographs to determine the variety of landscape preferences (Bulut and Yilmaz, 2008; Canas et al., 2009; Tveit, 2009; Sevenant and Antrop, 2010; Kurdoglu and Kurdoglu, 2010; Howley, 2011; Ozkan, 2014). There are many visual quality evaluation studies on various habitat types, including those on rural landscapes (Arriaza et al., 2004; Rogge et al., 2007), wetlands, rivers, lake-wetlands (Meitner, 2004; Bulut and Yılmaz, 2009; Zhao et al., 2013), forests (Eroğlu and Acar, 2011), agricultural landscapes (Matthies et al., 2010, Acar and Eroğlu, 2010 ), roadside and road corridors (Akbar et al., 2003; Clay and Smidt, 2004; Eroğlu at al., 2016), rocky habitats (Acar et al., 2013; Acar and Sakıc1, 2008), coastal landscape areas (Kalın, 2004; Ak, 2010), and mountainous areas (Eroğlu, 2012; Kalın et al., 2014). Most of these studies have attempted to assess the different settings found in a single habitat or to determine their seasonal changes. In the present study, habitats with different characteristics were selected and an attempt was made to determine the visual statuses among them.

The aim of this study was to assess the visual value of those areas that stand out with their natural landscape features and to determine the conservation status of the different habitat types in order to ensure their visual and ecological sustainability. Accordingly, visual landscape quality was assessed by photographing different types of visibly unique habitats which attract attention and can be seen along forest roads, in riparian areas, in forests, in rocky areas, in highlands, around waterfalls, in lakewetlands and in aquatic-dune areas. The relationship between the parameters and preferences were evaluated according to the fractal dimension and visual quality of the photographs.

\section{Material and Method}

\subsection{Study area}

The study areas selected were Anzer, Ayder, Sultanmurat, Çat Düzü and Taşlı (highlands), Efteni (lakewetlands) and Melen Ağzı (sand dunes) in the provinces of Düzce, Rize and Trabzon, located on the 
northern Black Sea coast of Turkey (Figure 1). The main reasons for choosing these areas were that they have unique natural beauty, they accommodate different habitat types, and they are locations with special vegetative status in Turkey.

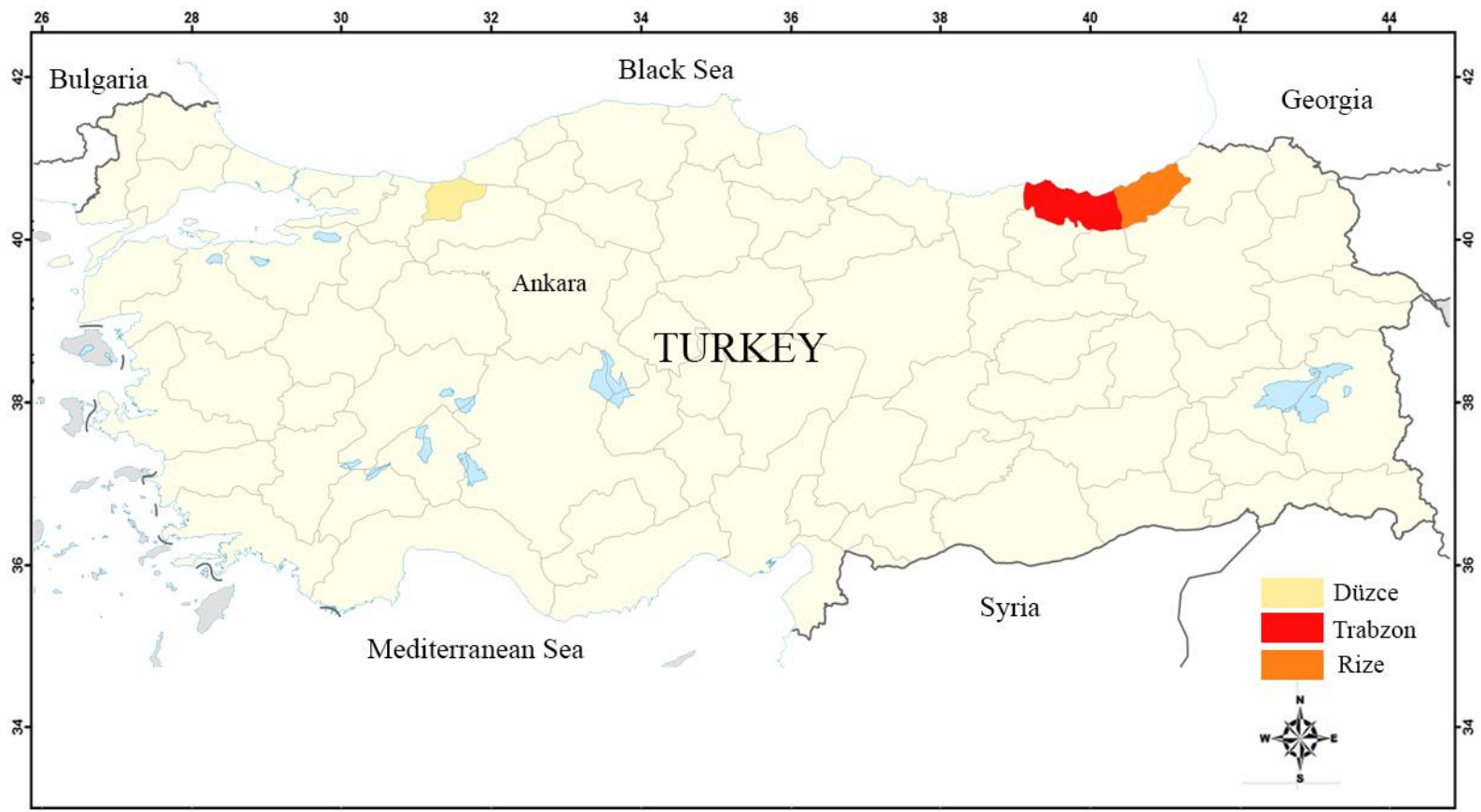

Figure 1. Map of Turkey showing study areas

\subsection{Material}

The natural materials of the study were the habitat types, and the visual materials were the photographs taken in these areas (Figure 2), which included forests, riparian areas, rocky habitats, roadside venues, waterfalls and highland vegetation located in Rize and Trabzon, and dunes and lake-wetlands located in Düzce.

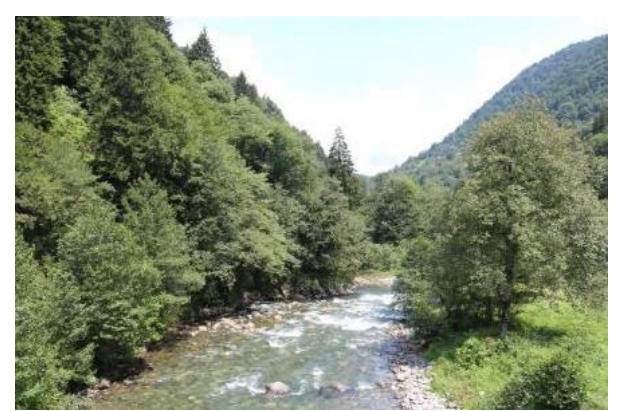

a.Riparian Area Vegetation

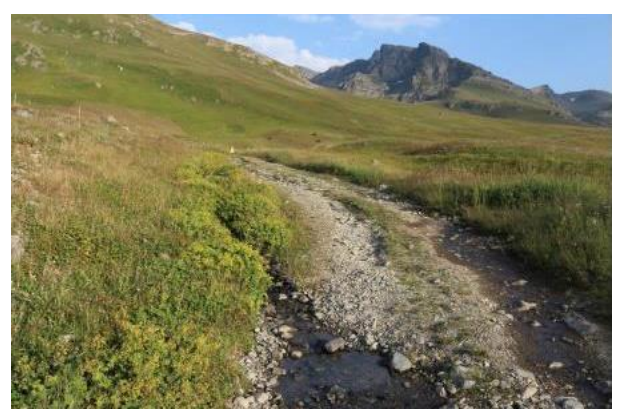

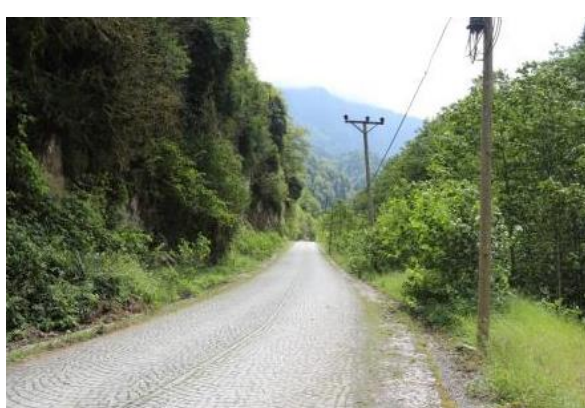

b.Roadside Vegetation

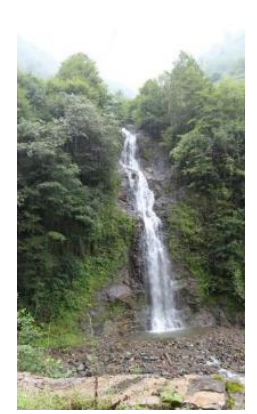

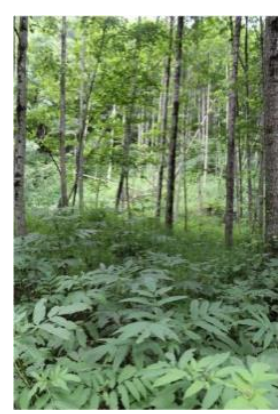

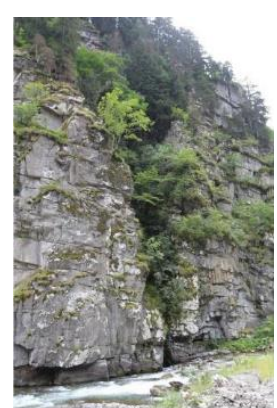

c.Rocky Area

Vegetation

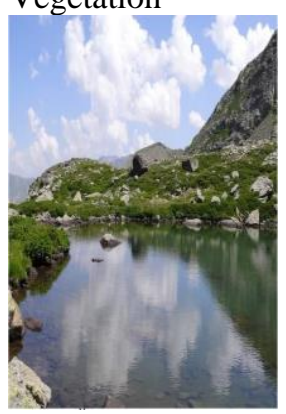




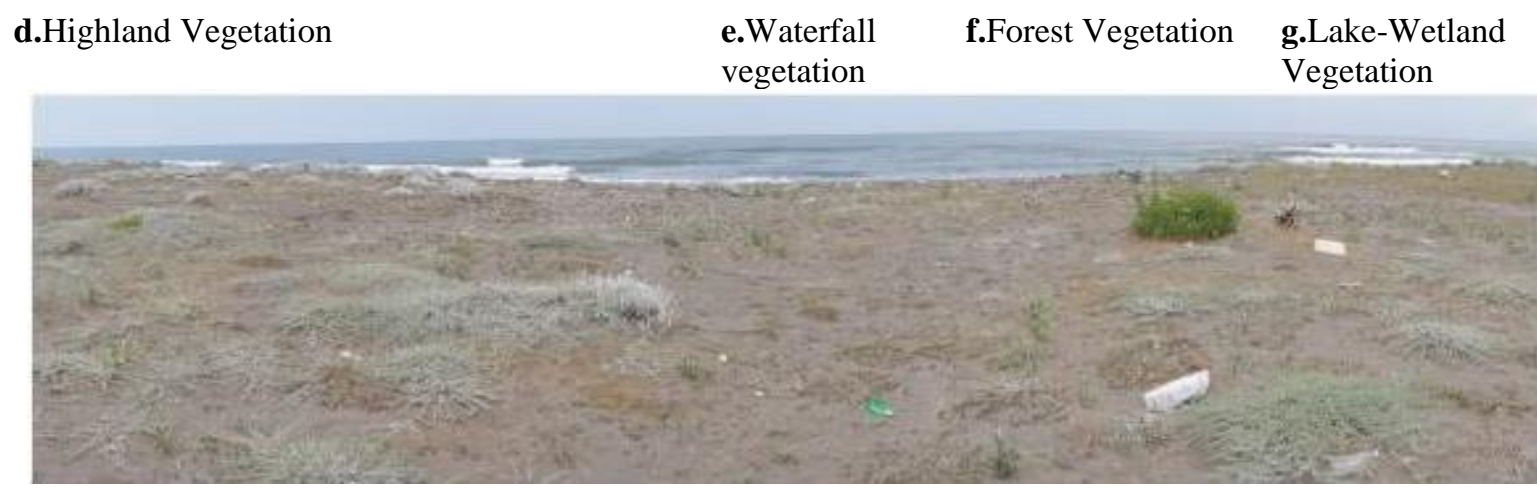

h.Dune area vegetation

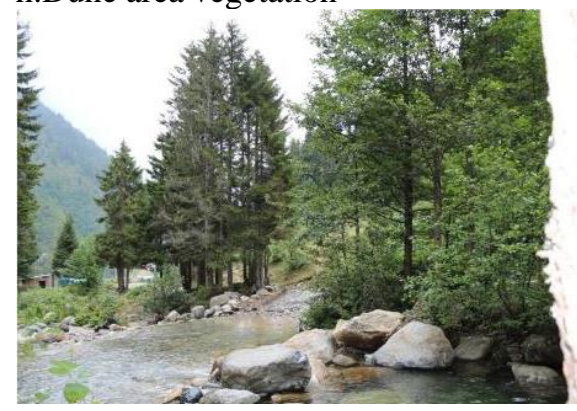

i.Riparian Area Vegetation

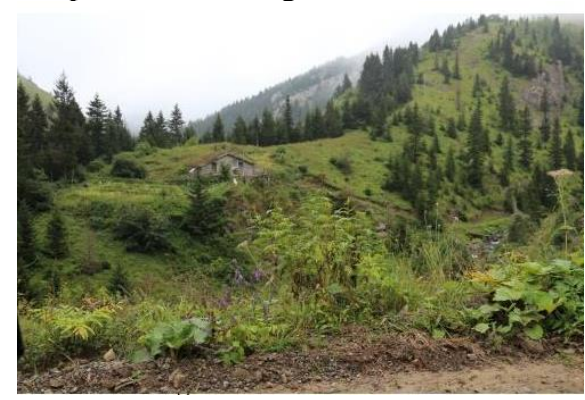

1.Highland Vegetation

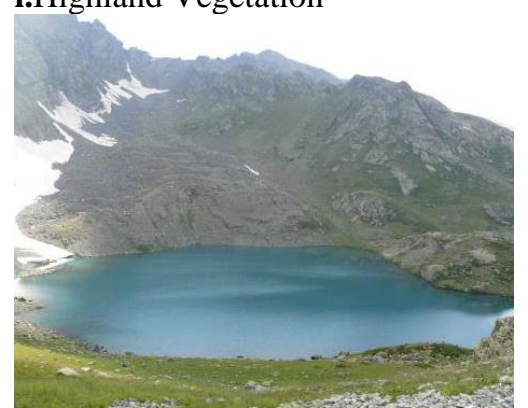

o.Lake-Wetland Vegetation

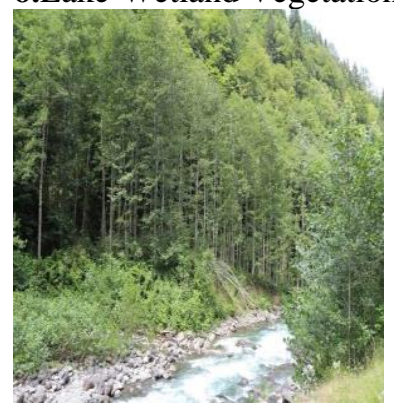

q.Riparian Area

Vegetation

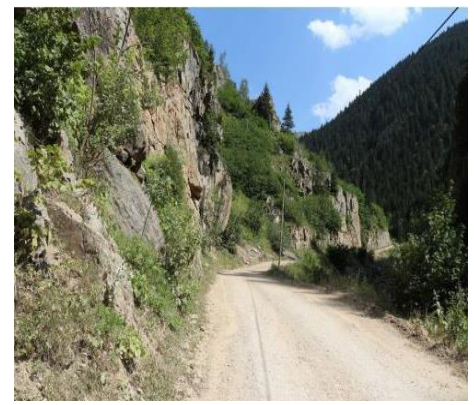

j.Roadside vegetation

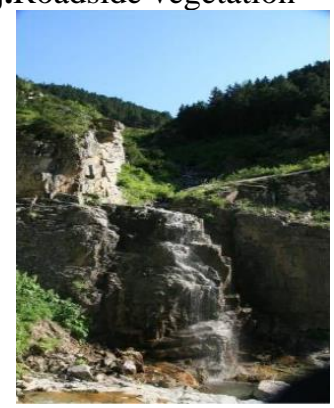

m.Waterfall vegetation

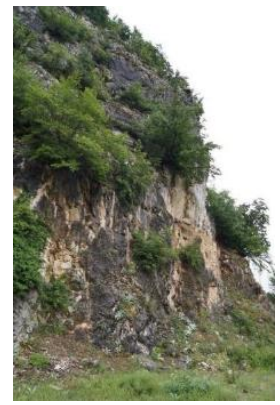

k.Rocky Area Vegetation

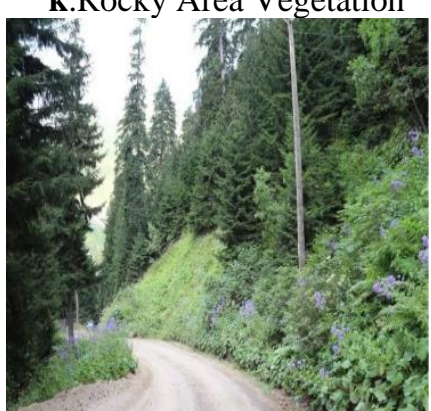

n.Forest Vegetation

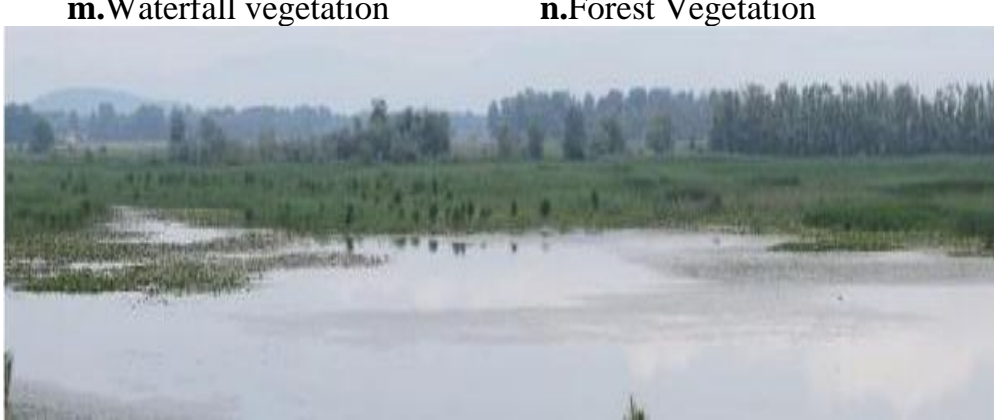

p.Dune Area Vegetation (Makalede Böyle Geçiyor)

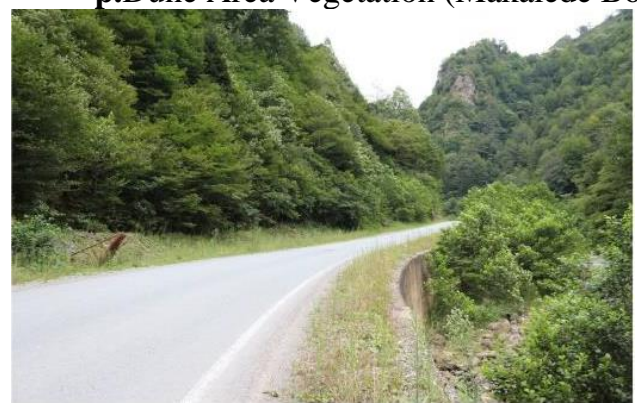

r.Roadside Vegetation

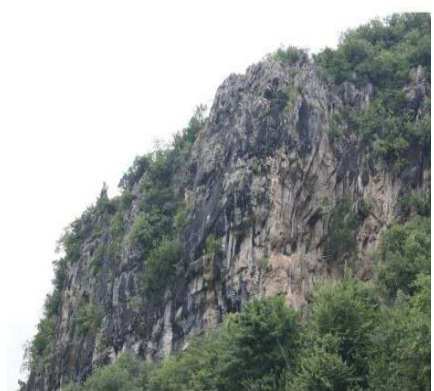

s.Rocky Area Vegetation 


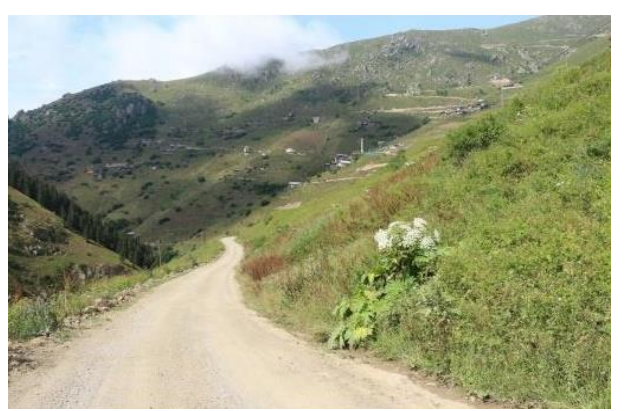

t.Highland Vegetation

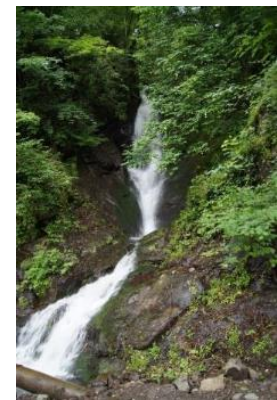

u.Waterfall Vegetation

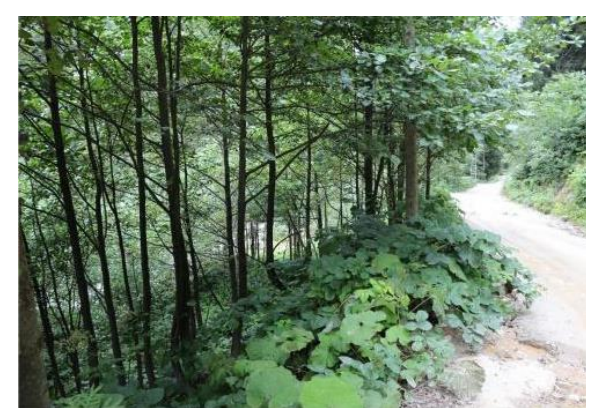

v.Forest Vegetation

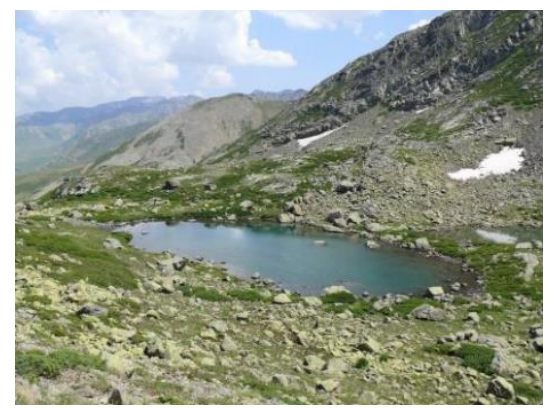

w.Lake-Wetland Vegetation

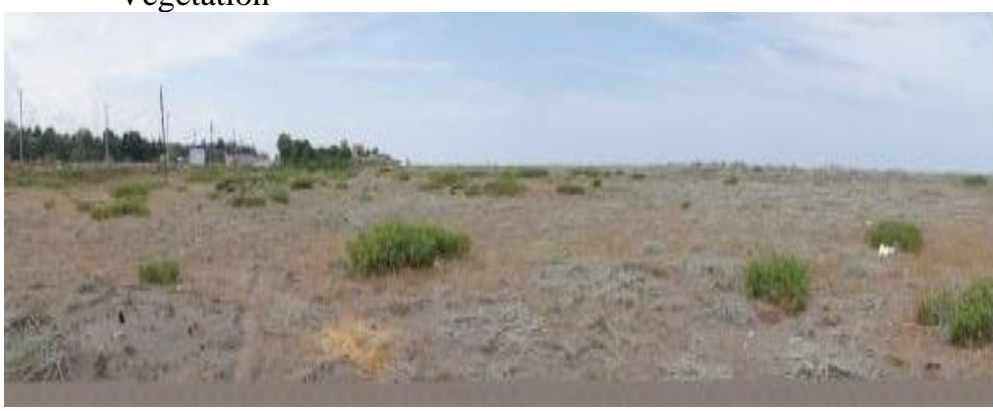

x.Dune Area Vegetation

Figure 2. Images of different habitat types used in the survey study

\subsection{Method}

The analysis of the visual quality, as the primary stage of the research method, was based on the Scenic Beauty Estimation Method developed by Daniel (1976) for visual quality estimation. This method is regarded as an effective means of revealing the reaction of viewers to groups of photographs (Carry, 1974; Kaplan, 1989; Amir at al., 1990) by enabling them to respond correctly and appropriately about the quality and visual evaluation of the landscape (Misgav, 2000; Kalın et al., 2014). In this study, which is discussed within this context, the purpose was to determine visual preference statuses of different habitat types by using visual evaluations. This method has been used in many previous studies (Clay at al., 2000; Clay at al., 2004; Fuante de Val et al., 2006; Acar et al., 2013; Acar and Kurdoğlu, 2005; Arriaza et al., 2004; Meitner 2004; Bulut at al., 2008; Eroğlu, 2012; Eroğlu, 2004; Eroğlu at al., 2016; Müderrisoğlu et al., 2006).

Typical images representing areas based on eight different habitat types were selected in order to determine visual landscape quality. Areas selected for the study were photographed in June and July 2015 in order to capture the most ideal vegetation period and to represent a remote overview of the habitats. In total, 941 photographs were taken in order to allow the assessment of the areas from all angles. The images were evaluated subjectively according to their picture quality, artificial elements in the picture such as cars, houses, infrastructural materials etc. and their ability to represent the habitat. Three examples from each habitat made up the 24 images used in the questionnaire.

\subsubsection{Questionnaire study}

With the help of the selected photographs, a questionnaire form was created for use in the visual landscape quality analysis. The questionnaire form prepared in the study framework was applied to 43 individuals representing three different groups (23 students, 16 local inhabitants and four lecturers).

The first part of the questionnaire concerned participant demographic characteristics such as gender, age, and educational and occupational status. In the second part, the participants were asked to evaluate visual preference situations such as naturalness, diversity, impressiveness, clarity, compatibility, interestingness, excitement and attractiveness by assigning between 1 (lowest) and 7 (highest) points to 
each photo. In the third part, they were asked to score conceptual parameters such as the conservation status of the area and activities recommended for that area.

\subsubsection{Statistical evaluations}

According to the results of the questionnaires, the data belonging to the different habitat types were subjected to statistical evaluations. The obtained variables were converted into a Microsoft Excel file as raw data. The SPSS 22 program was then used to determine the relationships between these data. The following materials were used in the research process:

- Descriptive statistics to determine the demographic status of participants and the visual values of different habitat types and photo groups

- Correlation analysis in determining the reciprocal relationships between visual parameters and different habitat types and groups of photographs

- Regression analysis in the identification of the parameters that were the most important factors in determining the visual preferences of different habitat types and groups of photographs

The significance level was determined as $p<0.05$ or $p<0.01$. In the study, weighted means were assigned to the scores given for the visual qualities of the photographs by the individual study participants. These mean values were used to determine whether or not the preferences of the participants differed according to their profession, sex, age, or educational status (Eroğlu, 2012; Sevenant et al., 2010; Akbar et al., 2002; Sarı, 2015.

\section{Research Findings}

\subsection{Habitat properties}

The eight different habitat types visually evaluated in the study and their general landscape characteristics are summarized in Table 1.

Table 1. Habitat types and general landscape features

\begin{tabular}{|c|l|}
\hline Habitat & \multicolumn{1}{c|}{ General features } \\
\hline types & $\begin{array}{l}\text { Rocky surfaces create a barrier for the surrounding vegetation due to the combination } \\
\text { of factors such as low water retention capacity, shortage of nutrients, seed holding and } \\
\text { germination difficulties, and greater wind and sun exposure. Many Alpine plants are } \\
\text { Vegetation } \\
\text { currently being used in landscaping and botanical design due to popular demand. It is } \\
\text { generally possible to find succulent ground cover as well as Juniperus communis var. } \\
\text { alpina, Vaccinium myritillus, Rubus spp. and occasionally woody species such as Picea } \\
\text { orientalis in rocky vegetation habitats. }\end{array}$ \\
\hline Riparian & $\begin{array}{l}\text { This includes true riparian vegetation and the wider vegetation band which affects the } \\
\text { stream, covering only a narrow area and characterized by changes in water level and } \\
\text { high soil moisture. Riparian habitats consist of streams, pebbles, stones, rocks, and } \\
\text { water-tolerant plants that love humid soil. In addition to important herbaceous species } \\
\text { and ground cover such as moss and fern, Alnus glutinosa species are also found in these } \\
\text { places. }\end{array}$ \\
\hline Waterfall & $\begin{array}{l}\text { This consists of cold-resistant plants which have high moisture and low heat demands, } \\
\text { the most common types being fern, moss species, Fagus orientalis, Carpinus betulus, Ilex } \\
\text { colchicum and Rhododendron ponticum. Plants found in these areas are similar to those of } \\
\text { riparian habitats. }\end{array}$ \\
\hline Vegetation
\end{tabular}




\begin{tabular}{|c|l|}
\hline Highland & $\begin{array}{l}\text { This type consists of herbaceous ground cover plants of changeable nature found in the } \\
\text { Eastern Black Sea highlands and also includes dwarf grass species. }\end{array}$ \\
\hline Vegetation & $\begin{array}{l}\text { The trees, shrubs and ground cover types in this habitat must be hardy because of their } \\
\text { constant exposure to passing vehicles. Picea orientalis, Alnus glutinosa, Fagus orientalis } \\
\text { species, as well as campanula, fern and some invasive ground cover species are } \\
\text { included among roadside vegetation. }\end{array}$ \\
\hline Dune & $\begin{array}{l}\text { The concepts of "sand" and "dune" cannot be considered separately. Sand is a soil } \\
\text { component which is resistant to decomposition and rich in minerals. In order to for a } \\
\text { dune to form in a place, a sand source must be present. However, dunes do not form in } \\
\text { every sandy area, but must be supported by other factors. Dune vegetation includes } \\
\text { shrubs and ground cover, with the most important plant species of this vegetation type } \\
\text { being Pancratium maritimum and Centaurea kilea. }\end{array}$ \\
\hline Forest & $\begin{array}{l}\text { This basically consists of trees. Forest trees include Picea orientalis, Fagus orientalis, } \\
\text { Carpinus betulus and Alnus glutinosa. Also included are shrubs, ground cover and } \\
\text { undergrowth such as Vaccinium arctostophyllos, Rhododenron ponticum, Rhododendron } \\
\text { luteum and ferns. }\end{array}$ \\
\hline $\begin{array}{c}\text { Lake- } \\
\text { wetland }\end{array}$ & $\begin{array}{l}\text { This comprises plants that love stagnant water and have a high demand for humidity, } \\
\text { mainly ground cover or shrubs including wetland plants such as Typha spp., Nymphaea } \\
\text { sp., Nuphar sp. Stones and rock fragments are typically found around lake-wetland } \\
\text { areas. }\end{array}$ \\
Vegetation
\end{tabular}

\subsection{Demographic characteristics of participants}

According to data obtained from the questionnaires, Table 2 shows that there are 43 participants, $60 \%$ male and $40 \%$ female. The highest participation rate in the age group category $(68 \%)$ was of those ranging from 20-30 years old. In terms of education, illiterate individuals and primary-high school students had the highest participation rate $(44 \%)$, whereas the ones who were studying at university had the lowest participation rate (12\%). Regarding professional status, the highest participation rate was that of students $(54 \%)$, with $37 \%$ allotted to other professions and the lowest participation rate belonging to teaching staff $(9 \%)$.

Table 2. Demographic characteristics of participants

\begin{tabular}{|c|c|c|c|}
\hline $\begin{array}{c}\text { Participant } \\
\text { Features }\end{array}$ & & Number & Percentage $(\%)$ \\
\hline \multirow{2}{*}{ Gender } & Female & 18 & 60 \\
\hline & Male & 25 & 40 \\
\hline \multirow{3}{*}{ Age } & $20-30$ & 29 & 68 \\
\hline & $30-40$ & 8 & 19 \\
\hline & $40<$ & 6 & 13 \\
\hline \multirow{3}{*}{ Education } & None & 19 & 44 \\
\hline & High school & 19 & 44 \\
\hline & College and above & 5 & 12 \\
\hline \multirow{3}{*}{ Occupation } & Student & 23 & 54 \\
\hline & Educational staff (lecturers) & 4 & 9 \\
\hline & Other & 16 & 37 \\
\hline
\end{tabular}




\subsection{Visual characteristics of habitats}

According to the arithmetic means of the photographs (referred to by their numbers) used in the questionnaire (Table 3), the most natural one was 21 and the most unnatural one was 8 , the most diverse was 21 and the least diverse 8 , the most impressive was 21 and the least impressive 24 , the clearest was 21 and the least clear 24, the most compatible was 21 and the least compatible 8, the most interesting was 21 and the least interesting 8 , the most exciting was 21 and the least exciting 8 , the most attractive was 21 and the least attractive 24 .

Table 3. Visual quality values of the photographs (arithmetic means)

\section{Arithmetic means}

\begin{tabular}{|c|c|c|c|c|c|c|c|c|}
\hline 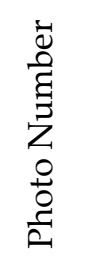 & 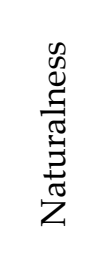 & 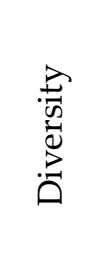 & 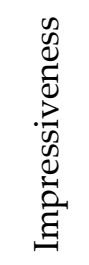 & $\begin{array}{l}\overrightarrow{\vec{\Xi}} \\
\frac{\vec{U}}{U}\end{array}$ & 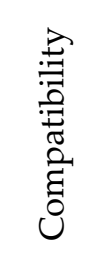 & 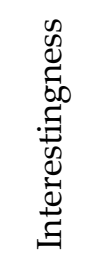 & 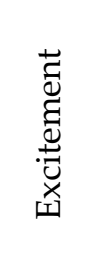 & 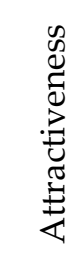 \\
\hline 1 & 6.30 & 4.42 & 5.23 & 5.16 & 5.88 & 3.98 & 5.07 & 4.21 \\
\hline 2 & 5.07 & 4.51 & 4.72 & 5.12 & 4.74 & 4.09 & 4.63 & 4.98 \\
\hline 3 & 6.30 & 5.49 & 5.86 & 5.79 & 5.65 & 5.77 & 5.79 & 5.72 \\
\hline 4 & 5.79 & 4.28 & 4.53 & 4.74 & 4.98 & 4.23 & 4.33 & 4.51 \\
\hline 5 & 6.40 & 5.70 & 6.14 & 5.79 & 5.91 & 5.67 & 6.12 & 6.23 \\
\hline 6 & 6.23 & 4.93 & 4.72 & 4.98 & 5.51 & 4.37 & 4.37 & 4.63 \\
\hline 7 & 6.30 & 5.09 & 5.70 & 6.07 & 5.74 & 5.26 & 5.51 & 5.67 \\
\hline 8 & 4.93 & 3.35 & 3.44 & 4.05 & 3.42 & 3.12 & 3.14 & 3.60 \\
\hline 9 & 6.40 & 6.09 & 6.19 & 6.07 & 6.05 & 5.77 & 5.93 & 6.12 \\
\hline 10 & 5.91 & 5.21 & 5.05 & 5.07 & 5.19 & 4.72 & 4.84 & 5.05 \\
\hline 11 & 6.26 & 5.28 & 5.47 & 5.40 & 5.56 & 5.47 & 5.33 & 5.33 \\
\hline 12 & 6.51 & 6.19 & 6.19 & 6.23 & 6.30 & 5.98 & 6.00 & 6.19 \\
\hline 13 & 6.42 & 6.07 & 6.02 & 6.02 & 6.14 & 6.09 & 6.07 & 6.05 \\
\hline 14 & 6.14 & 5.86 & 5.67 & 5.86 & 5.84 & 5.49 & 5.60 & 5.74 \\
\hline 15 & 6.51 & 5.28 & 5.81 & 6.05 & 5.86 & 6.09 & 5.74 & 5.91 \\
\hline 16 & 5.88 & 5.05 & 4.56 & 4.63 & 5.16 & 4.67 & 4.47 & 4.51 \\
\hline 17 & 6.56 & 6.23 & 6.33 & 6.19 & 6.26 & 5.60 & 5.91 & 6.19 \\
\hline 18 & 5.58 & 5.21 & 5.07 & 5.33 & 4.98 & 4.74 & 4.84 & 5.07 \\
\hline 19 & 6.49 & 5.21 & 5.81 & 5.56 & 5.79 & 5.98 & 5.84 & 5.58 \\
\hline 20 & 6.30 & 5.81 & 5.51 & 5.60 & 5.58 & 5.26 & 5.44 & 5.40 \\
\hline 21 & 6.77 & 6.33 & 6.49 & 6.42 & 6.47 & 6.40 & 6.42 & 6.40 \\
\hline 22 & 6.30 & 5.72 & 5.26 & 5.51 & 5.72 & 4.74 & 4.72 & 5.00 \\
\hline 23 & 6.30 & 5.72 & 5.26 & 5.51 & 5.72 & 4.74 & 4.72 & 5.00 \\
\hline 24 & 5.02 & 3.70 & 3.30 & 3.58 & 3.53 & 3.42 & 3.19 & 3.21 \\
\hline Total & 6.12 & 5.23 & 5.33 & 5.42 & 5.48 & 5.08 & 5.17 & 5.25 \\
\hline
\end{tabular}

The visual quality values of the habitat types are given in Table 4 . Among the eight habitats in the survey, the most natural one was the waterfall habitat and the least natural one the dune habitat, the most diverse was the waterfall habitat and the least diverse the dune habitat, the most impressive was the waterfall habitat and the least impressive the dune habitat, the clearest was the waterfall habitat and the least clear the dune habitat, the most compatible was the waterfall habitat and the least compatible 
the dune habitat, the most interesting was the waterfall habitat and the least interesting the dune habitat, the most exciting was the waterfall habitat and the least exciting the dune habitat, the most attractive was the waterfall habitat and the least attractive the dune habitat.

Table 4. Visual quality values of habitat types (arithmetic means)

\begin{tabular}{|c|c|c|c|c|c|c|c|c|}
\hline \multicolumn{9}{|c|}{ Arithmetic means } \\
\hline $\begin{array}{c}\text { Habitat } \\
\text { Types }\end{array}$ & 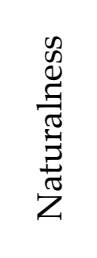 & 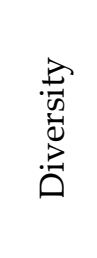 & 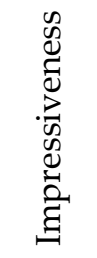 & 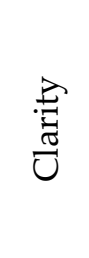 & 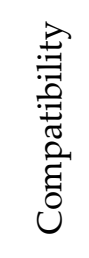 & 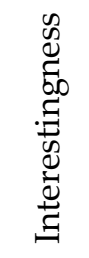 & 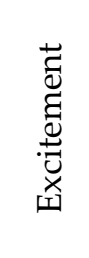 & 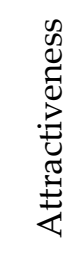 \\
\hline Riparian & 6.42 & 5.58 & 5.91 & 5.81 & 6.06 & 5.12 & 5.64 & 5.50 \\
\hline Roadside & 5.52 & 4.98 & 4.95 & 5.17 & 4.97 & 4.52 & 4.77 & 5.03 \\
\hline Rocky & 6.35 & 5.33 & 5.71 & 5.58 & 5.67 & 5.74 & 5.65 & 5.54 \\
\hline Highland & 6.20 & 5.43 & 5.41 & 5.53 & 5.62 & 5.16 & 5.26 & 5.36 \\
\hline Waterfall & 6.53 & 6.03 & 6.22 & 6.08 & 6.17 & 6.05 & 6.20 & 6.22 \\
\hline Forest & 6.22 & 5.50 & 5.22 & 5.45 & 5.69 & 4.87 & 4.90 & 5.12 \\
\hline $\begin{array}{c}\text { Lake- } \\
\text { Wetland }\end{array}$ & 6.43 & 5.00 & 5.47 & 5.69 & 5.60 & 5.48 & 5.35 & 5.46 \\
\hline Dune & 5.28 & 4.03 & 3.77 & 4.09 & 4.04 & 3.74 & 3.60 & 3.78 \\
\hline Total & 6.11 & 5.23 & 5.33 & 5.42 & 5.47 & 5.08 & 5.16 & 5.25 \\
\hline
\end{tabular}

When the correlation analysis in Table 5 is examined, the scores for the survey photographs according to gender status show that the naturalness, diversity, impressiveness, clarity, compatibility, excitement, and attractiveness gradually decreased from males to females. Namely, the men found the photographs more natural or more interesting than the women did. As the ages of the participants increased, the perception of naturalness also increased. Although the older participants found the photographs more natural, the younger ones saw them as less natural. As educational status increased, the perception of naturalness, diversity, and clarity also increased in direct proportion. The university graduates found the photographs more natural, diverse and clear than the illiterate participants, while the high school students found the photos less natural than the university students. According to occupational status, the perception of naturalness was higher for other occupations than for the students, whereas the sense of interestingness, excitement, and attractiveness of the lecturers was higher than for the students and other occupations. Thus, although the students found the photos less natural, the lecturers found them more natural, and the lecturers and students saw the photos as more interesting, exciting and attractive, while those in other professions found them to be less interesting, exciting and attractive.

Table 5. Relationship between demographic status and conceptual parameters (correlation analysis) 


\section{Correlation}

\begin{tabular}{|c|c|c|c|c|c|c|c|c|c|}
\hline & & 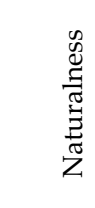 & $\begin{array}{l}\stackrel{\overrightarrow{0}}{0} \\
\stackrel{0}{0} \\
\stackrel{D}{0}\end{array}$ & 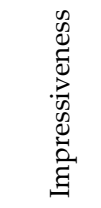 & $\begin{array}{l}\stackrel{\vec{E}}{\vec{U}} \\
\vec{U}\end{array}$ & 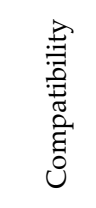 & 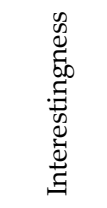 & 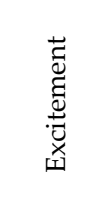 & 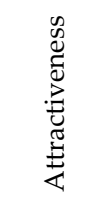 \\
\hline \multirow[t]{2}{*}{ Gender } & P.C. & $-.143^{* *}$ & $-.165^{* *}$ & $-.117^{* *}$ & $-.090^{* *}$ & $-.076^{*}$ & $-.126^{* *}$ & $-.117^{* *}$ & -.038 \\
\hline & Sig. & .000 & .000 & .000 & .004 & .015 & .000 & .000 & .219 \\
\hline \multirow[t]{2}{*}{ Age } & P.C. & $.123^{* *}$ & -.018 & -.039 & .033 & .036 & -.043 & -.059 & -.058 \\
\hline & Sig. & .000 & .567 & .208 & .282 & .254 & .165 & .057 & .063 \\
\hline \multirow[t]{2}{*}{ Education } & P.C. & $.119^{* *}$ & $.128^{* *}$ & .028 & $.080^{*}$ & .059 & .024 & -.009 & -.013 \\
\hline & Sig. & .000 & .000 & .367 & .010 & .057 & .448 & .764 & .683 \\
\hline \multirow[t]{2}{*}{ Occupation } & P.C. & $.151^{* *}$ & -.011 & -.051 & .035 & .045 & $-.104^{* *}$ & $-.137^{* *}$ & $-.109^{* *}$ \\
\hline & Sig. & .000 & .720 & .099 & .256 & .152 & .001 & .000 & .000 \\
\hline
\end{tabular}

Regression analysis was performed in order to examine the prominent parameters in determining the visual quality values of the different habitat types. Accordingly, the main determinants in the visual quality assessment of different habitat types were responses to conservation issues as well as to excitement, interestingness, and attractiveness (Table 6).

Table 6. Basic components determining visual quality values of habitat types (regression analysis)

\section{Coefficients}

\begin{tabular}{|c|c|c|c|c|c|c|}
\hline \multicolumn{2}{|c|}{ Model } & \multicolumn{2}{|c|}{$\begin{array}{c}\text { Unstandardized } \\
\text { Coefficients }\end{array}$} & \multirow{2}{*}{$\begin{array}{c}\text { Standardized } \\
\text { Coefficients } \\
\text { Beta }\end{array}$} & \multirow[t]{2}{*}{$\mathbf{t}$} & \multirow[t]{2}{*}{ Sig. } \\
\hline & & B & Std. Error & & & \\
\hline \multirow[t]{2}{*}{1} & (Constant) & 3.796 & .122 & & 31.062 & .000 \\
\hline & Conservation & .386 & .055 & .214 & 7.015 & .000 \\
\hline \multirow[t]{3}{*}{2} & (Constant) & 4.618 & .319 & & 14.484 & .000 \\
\hline & Conservation & .287 & .065 & .159 & 4.405 & .000 \\
\hline & Attractiveness & -.121 & .043 & -.101 & -2.790 & .005 \\
\hline \multirow[t]{2}{*}{3} & (Constant) & 4.390 & .322 & & 13.641 & .000 \\
\hline & Conservation & .314 & .065 & .173 & 4.815 & .000 \\
\hline
\end{tabular}




\begin{tabular}{lccccc}
\hline Attractiveness & -.306 & .064 & -.256 & -4.810 & .000 \\
\hline $\begin{array}{l}\text { Interestingnes } \\
\mathrm{s}\end{array}$ & .230 & .058 & .202 & 3.946 & .000 \\
\hline $\mathbf{4}$ & & & & & \\
\hline (Constant) & 4.509 & .325 & & 13.892 & .000 \\
\hline Conservation & .288 & .066 & .159 & 4.379 & .000 \\
\hline Attractiveness & -.214 & .074 & -.179 & -2.913 & .004 \\
\hline $\begin{array}{l}\text { Interestingnes } \\
\mathrm{s}\end{array}$ & .324 & .069 & .284 & 4.673 & .000 \\
\hline Excitement & -.201 & .081 & & & \\
\hline
\end{tabular}

\subsection{Opinions on the preservation of different habitats}

In the study, the participants were asked whether the presented habitat type should be preserved. According to their answers, the habitats illustrated in the numbered photographic images that should absolutely be protected were numbers a, c, e, i, l, m, n, o, q, s and $\mathrm{u}$. The areas that should be partially protected were numbers $b, d, f, g, j, k, p, r, t, v$ and $w$ while the habitat in number 8 was selected as being less in need of protection and number 24 was selected as being in need of intervention. Regarding the assessment of habitat level, responses indicated that the riparian $(\mathrm{a}, \mathrm{i} \& \mathrm{q})$ and waterfall $(\mathrm{e}, \mathrm{m} \& 21)$ habitats should absolutely be protected, whereas the roadside $(b, j \& r)$, the rocky $(c, k \& s)$, the highland $(\mathrm{d}, 1 \& \mathrm{t})$, the forest $(\mathrm{f}, \mathrm{n} \& \mathrm{v})$ and the lake-wetland $(\mathrm{g}, \mathrm{o} \& \mathrm{w})$ habitats were in need of partial protection. The dune area habitat $(\mathrm{h}, \mathrm{p} \& \mathrm{x})$ was considered as needing less protection.

\subsection{Recreational potential of different habitats}

Participants who viewed the different habitat types were asked what kind of activities they wanted to conduct in that area. Hiking/trekking, with 112 responses, was the most recommended activity, and was suggested for photos $b, j$ and $v$. In other words, this activity was recommended for the roadside and forest habitats. The second most selected activity was photography, with 73 responses, mainly for photos c, e, k, s and u, which were the rocky and waterfall habitats. The third most suggested activity was picnicking, with 53 responses, mostly for photos a and q, which were riparian habitats. Other preferred activities included camping (33 responses) in riparian and highland habitats, climbing (28 responses) in rocky habitats, bicycling (21 responses) in roadside and forest habitats, relaxing (21 responses) in rocky and lake-wetland habitats, fishing (19 responses) in dune and lake-wetland habitats, enjoying the scenery (16 responses) in lake-wetland habitats, motoring (13 responses) in roadside habitats, swimming (13 responses) in dune habitats, holidaying (9 responses) in highland habitats, swimming (7 responses) in riparian habitats, rafting ( 7 responses) in riparian habitats and animal husbandry ( 6 responses) in highland habitats. When the suggested activities were evaluated in terms of the habitats, the most preferred activities were picnicking in the riparian habitat, hiking in the roadside habitat, photography in the rocky habitat, hiking in the highland habitat, photography in the waterfall habitat, hiking in the forest habitat, camping in the lake-wetland habitat and swimming in the dune habitat.

\section{Results and Discussion}

\subsection{Visual evaluations of habitat types}


In the study, all the results obtained in the determination of the visual values of the habitat types were related to the demographic status of the participants, which was quite similar to findings of previous studies (Acar et al., 2013; Muderssioğlu et al., 2006; Eroğlu, 2012; Bulut and Yılmaz, 2008, 2009). The most prominent demographic feature was gender. Kaplan and Kaplan (1989) stated that there was an important relationship between gender and perception of natural formations and explained that male and female participants have different visual tendencies. The reduction of green zones in urban areas in particular has made the residents' views on natural areas even more diverse. The visual desire and tendency toward natural areas has generally been attributed to the decline of green areas under the pressure of urbanization. At the same time, the increasing trend towards biodiversity (i.e., increased vegetation cover) has also revealed a rising interest in these fields (Khew et al., 2014). According to the overall evaluations made by the participants, the general tendency in the visual preferences of habitats selected from natural areas was positive and the results obtained showed that an increase in diversity also affected the levels of appreciation and interest positively. There are differences between the visual preferences for changes in different landscape patterns and in perceptual tendencies towards natural and unnatural patterns, whether urban or rural; in particular, the size, variety and space-mass ratio of the pattern have different perceptual values (Chen et al., 2015).

One of the most important findings of this study was that the visual preference levels for different habitat areas based on water such as waterfalls and lake-wetlands were higher than for other landscape areas. Likewise, Kalın et al. (2014) pointed out that of the different landscape characters, the most favored ones are the landscape habitats close to water such as riparian and lake-wetlands. The lowest visual conservation value in the present study belonged to the dune type that had the least vegetation cover. From this viewpoint, areas where biodiversity was high due to the increase in water and vegetation cover were found to be more deserving of preservation. The presence of tree groups in a plant composition has been shown to be more favorable and preferable (Eroğlu, 2004, 2012; Zhao, 2013) and this study determined that preferability levels and appreciation were quite high for forest vegetation with intense tree coverage.

The most effective visual evaluation parameters regarding different plant compositions and different landscape characters were determined to be naturalness, continuity, interestingness and excitement. As a result of this study, the most effective visual evaluation parameters in determining the visual preferences of different habitat types were impressiveness, interestingness, and excitement.

\subsection{Recreational and conservation assessments of habitat types}

Soliva and Hunziker (2009) stated that areas which are protected and have protection status are more preferable than cultural landscape areas. At the same time, they emphasized that some highly appreciated areas have been determined as protected areas. This study indicated that areas with available protection status, such as wetlands and waterfalls, were more deserving of protection and had a higher visual preference. However, even when the vegetation status was low, the visual preference and protection status of the highland habitat was high. The main reason for this was the effect of the green color of the vegetation. In his study, Eroglu (2004) revealed that color is the most important element among perceptual factors and that the presence of green color in a composition affects the visual appreciation positively.

It is recognized that the kind of recreational pursuits preferred in different habitats is an important factor, especially in determining the need for natural areas. The demands for outdoor recreational activities are increasing day by day, and people want to perform such activities largely in natural areas (Kurdoğlu and Kurdoğlu, 2010). The different natural attractions of these areas play an important role in the diversity of such activities. Akbar et al. $(2002,2003)$ and Kent and Elliott (1995) have indicated 
that this situation is not only related to the visual values that these areas possess, but also to their biodiversity and landscape characteristics. Moreover, in this study, it was shown that different activity preferences such as hiking, photography, picnicking and camping were also related to the visual appreciation of these diverse habitat types. One of the most important findings of this study was that the most preferred recreational tendency for all habitat types, regardless of their diversity, was hiking.

\section{Conclusion and Recommendations}

In this study, it was determined that the most important factor in the appreciation of the natural areas was water (and habitat types associated with water). The more desirable images and habitats usually included a water element. Other images and habitats that did not include a water element were less preferred. It was concluded that those who viewed the different habitat types predominantly recommended hiking, photography, picnicking and camping in those habitats, respectively.

According to the results of the questionnaire, the most appreciated habitat type was the waterfall, while the sand dune habitat was the least appreciated. The habitats definitely determined to be in need of preservation were those of the riparian and waterfall, whereas the sand dunes were determined to require intervention.

In this, as in many such studies, the assessment and evaluation of the visual quality of a landscape were based on participant visual quality scores which depended on their appreciation of photographs. However, in determining the landscape character and visual quality of a natural landscape image through photographs, objective as well as subjective evaluations are useful. Different ecologically specific habitats contain vegetation types which offer an important visuality in terms of landscape. The sustainability of landscape aesthetics requires the preservation of the ecosystems that offer this visuality. Therefore, visual evaluation and analysis of different natural landscape components such as vegetation should be included in landscape planning and management studies.

\section{References}

Acar, C., \& Kurdoğlu, B. Ç. (2005). Visual quality evaluation in Kaçkar Mointains. Sum on protected natural areas. Isparta, Turkey: Süleyman Demirel University September 8-10, 2005.

Acar, C., Sakıcı. Ç. (2008) Assessing Landscape Perception of Urban Rocky Habitats. Building and Environment 43, 1153-1170.

Acar, C., Eroğlu, E. (2010) Visual preferences for poplar plantatıons on roadsıde landscape in TURKEY. Fifth International Poplar Symposium. Poplars and willows: From research models to multipurpose trees for a biobased society. 20-25 September 2010, Orvieto, Italy.

Acar, H., Eroglu, E., Acar, C. (2013) Landscape values of rocky habitats in urban and semi-urban context of Turkey: A study of Tokat city. Journal of Food Agriculture \& Environment 11(2), 1200-1211.

Ak, M. K. (2010) Akçakoca Kıyı Bandı Örneğinde Görsel Kalitenin Belirlenmesi ve Değerlendirilmesi Üzerine Bir Araştırma. Ph.D. thesis, A. Ü. Fen Bilimleri Enstitüsü Peyzaj Mimarlığı ABD, Ankara, Turkey.

Akbar, K. F., Hale, W. H. G., Headley, A. D. (2002). Assessment of scenic beauty of the roadside. Landscape and Urban Planning 959, 1-6.

Akbar, K. F., Hale, W. H. G., Headley, A. D. (2003) Assessment of scenic beauty of the roadside vegetation in northern England. Landscape and Urban Planning 63, 139-144.

Amir, S., Gidalizon, E. (1990) Expert-based method for the evaluation of visual absorption capacity of the landscape. Journal of Environmental Management 30, 251-263.

Angileri, V., Toccolini, A. (1993) The assessment of visual quality as a tool for the conservation of rural landscape diversity. Landscape and Urban Planning 24(1-4), 105-112. 
Arriaza, M., Ortega, J.F.C., Medueno, J.A.C., Aviles, P.R. (2004) Assessing the visual quality of rural landscapes. Landscape and Urban Planning 69 (1), 115 - 125.

Bulut, Z., Yilmaz, H. (2008) Determination of Landscape beauties through visual quality assessment method: A case study for Kemaliye (Erzincan/Turkey). Environmental Monitoring and Assessment 141, 121-129.

Bulut, Z., Yılmaz,H. (2009) Determination of waterscape beauties through visual quality assessment method. Environmental Monitoring and Assessment 154, 459-468.

Canas, I., Ayuga, E., Ayuga, F. (2009) A contribution to the assessment of scenic quality of landscapes based on preferences expressed by the public. Land Use Policy 26, 1173-1181.

Chen, Z., Xu, B., Devereux, B. (2015) Assessing public aesthetic preferences towards some urban landscape patterns: The case study of two different geographic groups. Environmental Monitoring Assessement 188(4), 1-17.

Clay, G., R., Daniel, T., C., (2000). Scenic Landscape Assessment: The Effects of Land Management Jurisdiction on Public Perception of Scenic Beauty. Landscape and Urban Planning, 49(1-2), P: $1-13$.

Clay, G.R., Smidt, R. K. (2004) Assessing the validity and reliability of descriptor variables used in scenic highway analysis. Landscape and Urban Planning 66, 239-255.

Daniel, T. C., Vining, J. (1983) Methodological issues in the assessment of landscape quality. In: I. Altman \& J. F. Wohwill (Eds.) Behaviour and the Natural Environment. Plenum: New York, pp. 39-83.

Daniel, T., C., (1976). Measuring Public Arsthetis Preference. In: Thames, J. (Ed.), Disturbed Land Reclamation and Use in the Southwest. University of Arizona Press, Tucson.

Erdönmez, M. Ö., Kaptanoğlu, Y.Ç. (2008) Peyza Estetiği ve Görsel Kalite Değerlendirmesi. İstanbul Üniversitesi Ormancllık Dergisi 58(1), 39-51.

Eroğlu, E. (2004) Examining the Seasonal Variation of Some Plants and Plants Groups in Düzce City Open and Green Areas on Planting Design Perception. Master's Thesis, Abant Izzet Baysal University, The Graduate School of Natural and Applied Sciences Landscape Architecture Graduate Program, Bolu, Turkey.

Eroğlu, E. (2012) Defining of Native Plant Compositions Determined Landscape Character in Mountainous Area Roadside Corridors: A Case Study Of Ataköy-Sultanmurat-Uzungöl-sulak alan Roadside Corridor. Karadeniz Technical University, The Graduate School of Natural and Applied Sciences Landscape Architecture Graduate Program.

Eroğlu, E., Acar, C. (2011) Visual landscape character of oriental spruce (Picea orientalis (L.) LINK.) mountain forests in Turkey. Journal of Environmental Engineering and Landscape Managment 19(3), 189-197.

Eroğlu, E., Demir, Z. (2016). Phenological and Visual Evoluations of some Roadside Deciduous Trees in Urban Area, Biological Diversity and Conversation, 9(1), P: 143-153.

Fuente de Val, G., D., L., Atauri, J., A., Lucio, J., V., D., (2006). Relationship Between Landscape Visual Attributes and Spatial Patten Indices: A test Study in Mediterranean-Climate Landscapes, Landscape and Urban Planning, 77(4), P: 393-407.

Howley, P. (2011) Landscape aesthetics: Assessing the general public's preferences towards rural landscapes. Ecological Economics 72, 161-169.

Kalın, A. (2004) Çevre Tercih ve Değerlendirmesinde Görsel Kalitenin Belirlenmesi ve Geliştirilmesi: Trabzon Sahil Bandı Örneği. Unpublished Ph.D. thesis, K.T.Ü. Fen Bilimleri Enstitüsü, Trabzon, Turkey.

Kalın, A., Eroğlu, E., Acar, C., Çakır ,G., Güneroğlu, N., Kahveci, H., Gel, A. (2014) Visual quality in landscape character: Example of mountain-road corridor in Turkey. Journal of Balkan Ecology 17 (2), 161-180.

Kane, P.S. (1981) Assessing landscape attractiveness: A comparative test of two new methods. Applied Geography 1, 77-96. 
Kaplan, R., Kaplan, S. (1989) The experience of nature: A psychological perspective. Cambridge University Press: New York, ISBN 0-521-34139-6, pp. 13-39.

Kent, R. L., Elliott, C. L. (1995) Scenic routes linking and protecting natural and cultural landscape features: A greenway skeleton. Landscape and Urban Planning 33 (1-3), 341-357.

Khew, J. Y. T., Yokohari, M., Tanaka, T. (2014) Public Perceptions of Nature and Landscape Preference in Singapore. Human Ecology 42, 979-988.

Kıroğlu, E. (2007) Erzurum Kenti ve Yakın Çevresindeki Bazı Rekreasyon Alanlarının Görsel Peyzaj Kalitesi Yönünden Değerlendirilmesi. Master's thesis, Atatürk Üniversitesi Fen Bilimleri Enstitüsü. Erzurum, Turkey.

Kurdoglu, O., Kurdoglu, B. (2010) Determining recreational, scenic. and historical-cultural potentials of landscape features along a segment of the ancient Silk Road using factor analyzing. Environmental Monitoring and Assessment 170, 99-116.

Lambe, R. A. (1986) Commercial highway landscape reclamation: A participatory approach. Landscape and Planning 24(4), 353-385.

Matthies, P. L., Briegel, R., Schüpbach, B., Junge, X. (2010) Aesthetic perefence for a Swiss alpine landscape: The impact of different agricultural land-use with different biodiversity. Landscape and Urban Planning 98, 99-109.

Meitner, M.J. (2004) Scenic beauty of river views in the grand canyon: Relating perceptual judgments to locations. Landscape and Urban Planning 68, 3-13.

Misgav, A., (2000). Visual Preference of the Public for Vegetation Groups in Israel. Landscape and Urban Planning, 48(3-4), P: 143-159.

Müderrisoğlu, H., Ak, K., Aydın, Ş.Ö., Eroğlu, E. (2006) Visitor Satisfaction in the Example of Abant Nature Park. Journal of Balkan Ecology 9(1), 55-62.

Ozkan, U. Y. (2014) Assessment of visual landscape quality using IKONOS imagery. Environmental Monitoring and Assessment 186, 4067-4080.

Özkan, D.G., Alpak, M. E., Özbilen, A. (2015) Kent Görünümlerinde Görsel Tercih: Trabzon Şehrindeki Değişimin Algılanması Ve Değerlendirilmesi. Proceedings of INTCESS15- 2nd International Conference on Education and Social Sciences, 948-957.

Parsons, R.., Daniel, T.C. (2000) Good looking: In defense of scenic landscape aesthetics. Landscape and Urban Planning 60 (1), pp. 43-56.

Rogge, E., Nevens, F., Gulinck, H (2007). Perception of Rural Landscapes in Flanders: Looking Beyond Aesthetics, Landscape and Urban Planning, 82(4), p: 159-174

Sarı, D., Karaşah, B. (2015) Hatila Vadisi Milli Parkı'nda (Artvin) yer alan farklı vejetasyon tiplerinin görsel değerlendirmesi üzerine bir çalışması. Türkiye Ormancılık Dergisi 16(1), 65-74.

Sevenant, M., Antrop, M. (2010) The use of latent classes to identify individual differences in the importance of landscape dimensions for aesthetic preference. Land Use Policy 27 (3), 827-842.

Soliva, R., Hunziker, M. (2009) How do biodiversity and conservation values relate to landscape preferences? A case study from the Swiss Alps. Biodiversity and Conservation 18, 2483-2507.

Tveit, M. (2009) Indicators of visual scale as predictors of landscape preference: A comparison between groups. Journal of Environmental Management 90, 2882-2888.

Zhao, J., Luo, P., Wang, R., Cai, Y. (2013) Correlations between aesthetic preferences of river and landscape characters. Journal of Environmental Engineering and Landscpae Managment 21 (2), 123-132.

Zhao, J. (2013) Woody Plant Richness and Landscape Preference. Master's thesis, Graduate School of Landscape Architecture, University of Illinois at Urbana-Champaign, Illinois, USA. 